\title{
Correspondence
}

\section{Learning and Sleep}

SiR,--Referring to the paper "Effect of Presenting Novel Verbal Material during Slow-wave Sleep" (Nature, 225, $873 ; 1970)$, the authors found nothing that was not already known from previous experiments ${ }^{1,2}$, although in recent investigations ${ }^{3}$ a $\mathbf{1 3}$ per cent recall of verbal material presented in stages $D$ and $E$ of natural sleep has been reported (personal communication from M. C. Levy).

The "sleep-learning" practised in the Soviet Union is incorporated into the hypnopaedie tutorial system, which is based on the audio-visual introduction of specially programmed training material in the pre-sleep waking state, followed by a number of further repetitions during 35-40 min coinciding with the onset of evening sleep. Speech signals are found to evoke intermittent alpha activity against a background of relatively low voltage mixed frequency electroencephalogram in these conditions, according to Soviet authors ${ }^{3-5}$, and the EEG is interpreted as hypnopaedic sleep. West German ${ }^{6}$ and Japanese ${ }^{7}$ investigators of "sleep-learning" came to similar conclusions as their Russian colleagues although through a different experimental approach. The common denominator between these studies is the superficial sleep between stages A2 and $\mathrm{C}$, as the psychophysiological background for the receptive state.

The purpose of further repetitions during the fluctuation of drowsiness and light sleep is the consolidation of the introduced (non-novel) training material which is also aided by the sleep which follows this process and reduces the effects of retroactive interferences.

Bruce et al. are not justified in extrapolating their findings, obtained in the laboratory, to the applied learning situation, for two main reasons. First, the presentation of the training material by Bruce et al. differs from that used in the applied sleep-learning situation and, second, the experimenters ceased to present the training material when the EEG approached stage B, thus preventing the development of hypnopaedic sleep. Russian investigators, on the other hand, continued the presentation of training material during stage $\mathbf{B}$, which has led to the theory of the hypnopaedic tutorial system ${ }^{3}$ based on psychophysiological findings. The Russian system of a sleop-learning method is part of this general framework which does not attempt to feed in novel verbal material during slow-wave sleep.

Soviet authors make no "unusual claims", as stated by Bruce et al., whom I assume cannot have studied the existing Russian literature ${ }^{3-5,8}$ and other $\mathrm{r}^{6,7,9}$ relevant material, which is indeed not quoted by them. I agree that learning does not occur in slow-wave sleep but that does not by itself invalidate the sleep-learning method. A balanced view on this subject requires a thorough study of the hypnopaedic tutorial system in all its aspects.

\section{Yours faithfully,}

55 Belsize Park,

\section{F. RUBIN}

\section{London NW3.}

${ }^{1}$ Simon, C. W., and Emmons, W. H., J. E. Psych., 51, 89 (1956).

${ }^{2}$ Simon, C. W., and Emmons, W. H., Amer. J. Psychol., 69, 76 (1956).

' Zukhar, V. T., Nautshniye i Praktisheskiye Voprossi Obticheniya s Ispolzovanigem Fstestvennogo Sna (Moscow, 1968).

- Bliznitchenko, L. A., Vvod i Sakrepleniye Informazzi v Pamyati Chcloveka vo Vremya Estestvennogo Sna (Kiev, 1966). -Vachmistrov, V. V., Angliiskii Yazek: Eksperimentalni Kurs s Isnoszo-

- Pieper, E., and Kugler, J., EEG and Clin. Neurophysiol., 21, 204 (1966).

'Tani, K., and Yoshli, N., Brain Res., 17, 277 (1970).

${ }^{s}$ Zenkevitsh, G. K., and Bagayeva, G. D., Iz Opyta Prymenieniya Gipnopedii pri Obuchenii Inostranim Yazikam (USSR Ac. of Sciences, 1968).

${ }^{9}$ Rubin, F.(ed.), Current Researeh in Hypnopaedia (Macdonald, London, 1968).

\section{Guide to Scientific MSS}

SIR,-Our unit is at present engaged in a series of sociological and archival studies of British men of science who flourished between 1830 and 1939. This work, which is supported by the Social Science Research Council, extends the scope of a joint committee of the Royal Society and the Historical Manuscripts Commission by including a much wider section of the scientific community of the period. We hope eventually to prepare a reference guide to existing collections of private papers, laboratory notes and professional correspondence; we believe that such a guide will be of great value to future biographers, and will provide an extremely important tool for later studies in the social, economic and intellectual history of science.

It is our experience that many manuscripts are still in private hands, left years ago in the kecping of friends, relatives and executors. In some cases, manuseripts are unintentionally allowed to slip out of the country, unrestricted by present export regulations. We have been successful in tracing some collections through libraries, national repositories, and through the Probate Registry at Somerset House. But in order to be as exhaustive as possible, we would greatly value the help of readers of Nature.

Individuals who are related, in any way, to a scientist - either amateur or professional-during this period, or who know of any holdings of manuscripts, no matter how small or apparently trivial, outside academic libraries or regional record offices, are invited to let us know.

Needless to say, we have no wish to inconvenience or disturb present owners of such papers. We merely hope to be as complete as possible in our stocktaking of these materials, which so often prove to be of great importance to the social and cultural background of Britain and the world of science.

Please send all comments to:

The Editor,

Archives of British Science,

Science Policy Research Unit,

University of Sussex,

Falmer,

Brighton BN1 9QZ.

Yours faithfully, R. M. MACLEOD

Science Policy Research Unit, University of Sussex.

\section{Quilos and Kilos}

Sur,--I have read with interest the various correspondence that has appeared in your journal over the last two years concerning the renaming of the unit of mass - the kilogramme-and would like to inform your readers of the following action that is being taken. Since 1967 technical publications and printing bodies such as the Institute of Printing have given much thought and consideration to this problem and they have decided to givo their' support for the new name "quilo", abbreviated by "q", as originally suggested by $\mathrm{M}$. Fulton (Nature, 218, 707; 1968) to replace the kilogramme. The present gramme $(\mathrm{g})$ would become the milliquilo $(\mathrm{mq})$.

The reason for this action is the difficulty introduced by the adoption of a multiple, the kilogramme (kg), as a basic unit. The advantage of the name "quilo" to replace the kilogramme is that it retains its familiarity. No doubt the retention of the name kilogramme is due to its extensive use in the metric countries. Despite this, it is considered completely illogical to have what is a unit in 
its own right, expressed as a multiple of another unit so that we can only express multiples and sub-multiples of the basic unit in terms of this other unit. It is anticipated that pressure will be brought to bear on our representatives on the Conférence Générale des Poids et Mesures, the International Standards Organization and the International Electrotechnical Commission committees, to bring their influence to bear on this matter in the near future. It is hoped that the engineering bodies will givo their support for the renaming of the kilogrammo. The "quilo" is the Portuguese name for the kilogramme.

I would like to add that the decimal-multiple $10^{3}$ may eventually be changed by international agreement from a lower case $k$ to a capital $K$, a step in the right direction at least.

It is understood that the name "quant" is under consideration by the British Standards Institution. Whatever the final choice may be, it is desirable that such a name should have as its abbreviation the least used letter of the alphabet--" $q$ ".

\section{Yours faithfully,}

\section{Allan B. Chick}

Head of Metrication and Standards,

Institution of Technical Authors

and Illustrators.

\section{Announcements}

\section{University News}

Dr G. C. Bond, head of the Catalyst Research Group, Johnson Matthey and Company, has been appointed to the chair of applied chemistry at Brunel University.

Dr C. W. Not, University of Birmingham, has been appointed to the chair of chemical engineering at HeriotWatt University.

\section{Appointments}

Sir Reay Geddes, chairman of the Dunlop Company, has been elected president of the Institution of the Rubber Industry.

Professor David M. Gates, Missouri Botanical Garden and Washington University, St Louis, has been appointed chairman of the Environmental Studies Board of the US National Academy of Sciences and National Academy of Engineering.

Mr J. S. Cripps, chairman of the Countryside Commis. sion, has been appointed a member of the Nature Conservancy, to succeed Baroness Wootion of Abinger. Mr H. A. Maxwell, Forestry Commission, and Professor C. H. Gimingham, University of Aberdeen, have joined the Conservancy's Scottish Committee; Mr I. H. Morten, Peak Park Planning Board, Mr C. F. Thring, Tmperial Chemical Industries, and Professor J. A. Steers, University of Cambridge, have joined the Committee for England; and Professor R. W. Edwards, University of Wales, and Dr G. M. Dunnet, University of Aberdecn, have joined tho Scientific Policy Committee.

\section{Miscellaneous}

The following have been elected. Foreign Members of the Royal Society: Dr H. B. G. Casimir, director of rescarch, Philips Gloeilampenfabriken; Professor J. Hämmerling, director of the Max-Planck-Institut für Zellbiologie; Professor A. Kornberg, head of the Biochemistry Department, Stanford University Medical School; Professor E. P. Wigner, Thomas D. Jones professor of mathematical physics, Princeton University.

The following awards have been made by the US National Academy of Sciences: George $P$. Merrill award, to Professor Klaus Keil, University of New Mexico; J. Lawrence Smith medal, to Dr E. P. Henderson, Smithsonian Institution; NAS award in microbiology, to Dr Earl R. Stadtman, US National Institutes of Health; US Steel Foundation award in molecular biology, to Professor A. Dale Kaiser, Stanford University School of Medicine; Mary Clark Thompson gold medal, to Dr
Raymond C. Moore, University of Kansas; Jesse Stevenson Kovalenko gold medal, to Dr Thomas Francis, jun. (posthumously).

A European Branch of the Environmental Mutagen Society will be established at a meeting at Neuherberg, near Munich, on July 10. Further details can be obtained from Professor F. H. Sobels, Department of Radiation (Kenetics, Transitorium voor Geneeskunde, Wassenaarseweg 62, Leiden, Holland.

A Nucleotide Group, affiliated to both the Biochemical Society and the Chemical Society, has recently been established, under the chairmanship of Profossor A. S. Jones, University of Birmingham. Further details can be obtained from the Secretary/Treasurer, Dr D. W. Hutchinson, School of Molecular Sciences, University of Warwick, Coventry CV4 7AL.

The Organization Internationale de Lutte Biologique (OILB) is to be enlarged and restructured to form the new International (Organization for Biological Control, to promote research into biological control in the broadest sense throughout the world. Provision will be made in the now statutes for individual, institutional and supporting membership, and for the creation of largely autonomous regional sections on a biogeographical basis. Professor Paul DeBach, University of California, has been nominated as president of the new organization, which it is hoped will be inaugurated early in 1971. A meeting to discuss UK participation in the prospective International Organization for Biological Control will be held at the Royal Society on May 20 at 11 a.m. The meeting is open to all who are interested, but accommodation is limited. Invitations can be obtained on request from the executive secretary of the Royal Society, 6 Carlton House Terrace, London SWI.

The Royal Society of Arts invites the submission, by any British firm or individual, of case studies illustrating "the successful use of new designs, innovations or discoveries which in recent years have contributed or in the next fow years will contribute significantly to the United Kingdom's export trade or balance of paymonts". Funds for the prizes, which total $£ 1,500$, have been provided by the Betro Trust and the Edgar F. Lawley Foundation. Entries should be sent, not later than September 30, to the secretary of the Royal Society of Arts, John Adam Street, London WC2N 6EZ.

Erratu M. In Fig. 2 of the article "Preliminary Geological Interpretation of a New Hominid Site in the Lake Rudolf Basin" by A. K. Behrensmeyer (Nature, 226, 225; 1970), the K-Ar date for the tuff in Koobi Fora should be $2 \cdot 6 \pm$ $0 \cdot 3 \mathrm{~m} \cdot \mathrm{y}$. 